\title{
Development of a curriculum and training program in Woman Veterans Health for Internal Medical Residents
}

\author{
MANJU CEYLONY ${ }^{1}$, JAHAN PORHOMAYON ${ }^{2}$, LEILI POURAFKARI ${ }^{2}$, NADER D. NADER ${ }^{2}$ \\ ${ }^{1}$ Department of Medicine, SUNY at Buffalo, Buffalo, NY, USA \\ ${ }^{2}$ Department of Anesthesiology, SUNY at Buffalo, Buffalo, NY, USA
}

\begin{abstract}
Introduction. Internal Medicine residents must develop competency as Primary Care Providers, but a gap exists in their curriculum and training with regard to women's reproductive health. With increasing need in VA due to new influx of women veterans it poses problems in recruitment of competent physicians trained in Women's health.

Methods. An intensive, one-month women's reproductive health curriculum with hands on experience for Internal Medicine residents was provided. Curriculum was taught to the residents who rotated at the Women's Health Clinic for one month. Pre-test and post-test exams were administered. Increase in knowledge of residents in providing gender specific evaluations and management was objectively assessed by changes in post-test scores. Data were analyzed for statistically significant improvement in written tests scores.

Results. Total of 47 Internal Medicine residents rotated through Women's Health Center during the evaluation period. All residents completed both pre-test and post-test exams. The average time to complete the pre-test was $20.5 \pm 5.4 \mathrm{~min}$ and $19.5 \pm 4.8 \mathrm{~min}$ for post-test. There was no correlation between the time to complete the pre-test exam and the post-test exam. The total score was significantly improved from $8.5 \pm 1.6$ to $13.2 \pm 1.8(\mathrm{p}<0.0001)$.

Conclusion. This study shows how to equip physicians in training with information on women's health that enables them to provide safe and gender appropriate care in primary care settings. This practice will reduce the need for frequent referrals for specialized care and thus provide cost saving for patient and health care on the whole.
\end{abstract}

Key words: Medical education; Women; Internship and Residency; Education; Primary health care.

\section{INTRODUCTION}

Women usually report higher levels of physical and psychological morbidity. Both biological and social factors may increase exposure or worsen the effects. Women risk contracting the same endemic diseases as men and both biological and social factors may increase exposure or worsen the effects [1]. There are a large number of chronic conditions that negatively affect the quality of life of women today. Although women's life expectancy is 7.5 years greater than that of men, the morbidity rates are significantly higher for women [2].

Men and women may experience similar diseases but rates of exposure and treatment vary between them. Strategies must be directed to gender-specific causes of mortality by age group. Gender-planned health services are planned on the basis that women and men play different roles in society and have different medical needs. National programs for women would allow co-ordination of broad-based programs to improve women's health and social position [3]. Regardless of where they live: poverty, birth rates and aging populations, gender, violence against women, and lack of research about women and lack of well-trained physicians in their special needs affects their overall health. Changing the perception of the problems unique to women, both healthcare and medical education can be improved to the benefit of all members of our society [1].

To date, most gender-specific health issues have been addressed to women's reproductive health needs and physicians trained in Obstetrics and gynecology were delivering this care. This left gaps in the care needs of women. Internists who were delivering bulk of the medical care were not trained or attuned to special needs of their women patients. They were being treated in a gender-neutral way along with male population.

Calls for addressing Women's health curriculum in training Medical Resident: The last decade has 
been marked by a rapid growth in the women's health movement around the world. A number of international conferences have been held to discuss women's health issues. According to the "World Development Report for 1993", women are considered to have a greater disease burden than men [2]. The new guidelines by Women Health Centre for Development and Population Activities calls to train primary care physicians to address these unique needs. The American Board of Internal Medicine has stated that women's health and genderspecific medicine should be included in internal medicine residency curricula. Education in women's health is now considered a core curricular component during residency training in Internal Medicine. Resident education in women's health is required but is often underemphasized [4]. Reflection on women's needs is still incomplete and has yet to be translated into operational programs [5]. US medical schools are making an effort in training medical students in women's health, but more is needed to ensure that women's health has an "academic home" within their institutions. Further efforts are required to secure adequate funding to train a cross-section of faculty in women's health. This is a reflection of the problem of inadequately trained physician work force and this propagates inadequate and poor training in women's health.

The Veterans Health Care Act was in 1992 initially Health Care Eligibility Reform Act requiring provision and then in 1996 there was Veterans' of high-quality services to female patients. According to the Veterans Affairs (VA) Center for Women Veterans, there are approximately 1.2 million women veterans in America today, and they make up approximately 15 percent of the active duty forces. This number is expected to grow upwards of 20$25 \%$ in the new millennium. VA is emerging as leader in furthering Women's health. VA has partnered with academic centers for clinical and educational improvement. Available fellowship programs have a goal of providing focused clinical, research, and educational training to prepare physicians from different backgrounds for careers in women's health. These "one-stop shopping" models, partnered with University-based women's health programs in women's health training have created models of care delivery not unlike carveouts designed to market women's health care in private sector settings [6]. These programs are geared towards one adequately trained physician being available to tend to needs of their female patients on a day to day basis and not need gyneco- logy specialist for mundane office diagnosis and procedure and acute care and hence avoid extra time and money commitment from patient.

\section{MATERIAL AND METHODS}

An initiative was started at VA Western New York Healthcare System to address this problem and to evaluate if this was the effective way to enhance the training of Internal medicine residents at The State University of New York at Buffalo in women's health. We hypothesize that this onemonth educational exposure will significantly enhance the residents' understanding of women's health issues. Information obtained from this study will be used as an education model that can be replicated on a larger scale nationwide with potential cost saving.

A curriculum was set up to encompass gender-specific medical problems seen exclusively in women and also evidence based screening guidelines for example for Pap smear test and screening test for osteoporosis. The curriculum for this rotation was designed to meet six-core competency guideline by the Accreditation Council for Graduate Medical Education and carried out to meet three main objectives [7]:

I. Foster Technical Skills: Medical Residents learn to do a good breast and Pelvic exam, Pap smear test and learn the interpretation of results. Able to do pelvic cultures and prepare potassium hydroxide and Saline slides and be able to identify under the microscope and treat common vaginal infections. To be able to assess for prolapse and learn management.

\section{II.Knowledge:}

1. Learn guidelines on preventive care of women with recent updates

2. Familiarity with hormone replacement and to learn the decision making process in their use.

3. Identification and management of urinary incontinence

4. Management of common menstrual disorders

5. Diagnosis and management of amenorrhea

6. Diagnosis and management of galactorrhea

7. Diagnosis and management of hirsutism

8. Management of osteoporosis with guidelines of testing, evaluation of results and application of different treatment options

9. Polycystic ovary syndrome with learning of diagnosis guidelines and etiology with its relationship with insulin resistance and metabolic syndrome

10. Contraception management 
11. Identification of pelvic inflammatory diseases and management

III. Learn to integrate these practices in their Medicine outpatient clinics.

Internal medicine residents have one month rotation at VA, Buffalo comprising of three $1 / 2$-days/ weeks. Goal was to institute a Curriculum to enhance a Medical Resident's knowledge and skills in taking care of a female patient's needs and unique gender specific problems. Two residents on the average go through this rotation at any given time. On the first day, they were given a package with goals of rotation and women's health curriculum. They were required to take a pre-test to evaluate their basic knowledge on the subject. Pre-test was based on medical clinical scenarios with the aim of addressing the curriculum [8]. This is in the form of multiplechoice answers. This pre-test was then corrected and explanation was given for each question and answer. Residents' understanding was explored and background information with references and guidelines were provided to the residents.

Residents performed all examination in the presence of faculty physician and techniques in office examinations and procedures were taught [9]. Medical residents are observed while interacting with patients and providing medical examinations, and given feedback [10-12]. Their assessments and plans were discussed and guided towards correct decision-making to address patient needs. Towards the end of rotation a post-test was taken and again all answers were discussed and background information was again provided to refine resident's judgment in practice.

\section{DATA COLLECTION AND STATISTICAL MODEL}

Data collected for each resident included the time that he/she took to complete pre-test and posttest exams. Total possible score for each test was "18". The percentages of correct answers were calculated for educational subsections of either pretest or post-test. Continuous variable [time to complete the test] was missing for 4 residents in pretest and 5 residents in post-test. The missing entered according to their PGY-specific median values (20 minutes for PGY-II and 19 minutes for PGY-III residents). Missing data variables were treated as above to limit the introduction of bias by their exclusion.

Post-test scores were used as the primary outcome variable for further analyses. Paired t-test was used to analyze pre-test scores to post-test scores. Since there were only two levels of training for resident (PGY-II and PGY-III), mean values of continuous variables were compared by Student $t$ test using two-tailed independent sampling and assumption of equal variance. Linear regression analysis with correlation matrix was performed to examine the correlation that may exist between pretest and post-test time and scores. Tests were 2-tailed, and values of $P<0.01$ were considered statistically significant. Data were presented as means \pm standard deviation and null hypotheses were rejected at $\mathrm{P}<0.05$. Statistical analysis was performed with NCSS-2007 software version 1.12 (NCSS LLC, Kaysville, UT).

\section{RESULTS}

A total of 47 Internal Medicine residents rotated through Women's Health Center during the evaluation period. The level of training for 23 residents was post-graduate year (PGY) II and for 24 residents was PGY-III. All of these residents completed pre-test exam and post-test exam at the beginning and the end of their rotation. The average duration of time that the residents took to complete the pretest exam was $20.7 \pm 5.1$ minutes. There was no difference between the time it took for the residents to complete the pre-test and posttest exam (19.5 \pm 4.5 minutes). Additionally, there was no correlation between the total scores and the time to complete the tests among the residents $(\mathrm{R} 2=$ $0.0008, \mathrm{P}=0.87$ ), However, there was a strong correlation between the time that the residents took to complete the pre-test and post-test $(\mathrm{R} 2=0.62$, $\mathrm{P}<0.02$ ). Furthermore, the time required to complete either pre-test or post-test was similar between PGY-II residents and PGY-III residents (Figure 1).

Maximum possible score was 18 in both pretest and post-test exams. The total score was significantly improved from $8.5 \pm 1.6$ to $13.2 \pm 1.8$ $(\mathrm{p}<0.0001)$. This improvement was similar between PGY-II and PGY-III residents (Figure 2). Improvement in test scores was uniform among all educational subsections of Women's Health rotation (Figure 3). The improvement in medical knowledge, as observed by increasing the total score of post-test from their pre-test scores, ranged from $10 \%$ in "incontinence" to $39 \%$ in "PAP smear" section.

In order to examine whether the residents' previous knowledge was instrumental in their posttest scores, we correlated the scores of pre-test exam with the scores of the post-test exam (Figure 4). There was no correlation between the scores of pretest and post-test exams $\left(\mathrm{R}^{2}=0.0023, \mathrm{P}=0.57\right)$. 


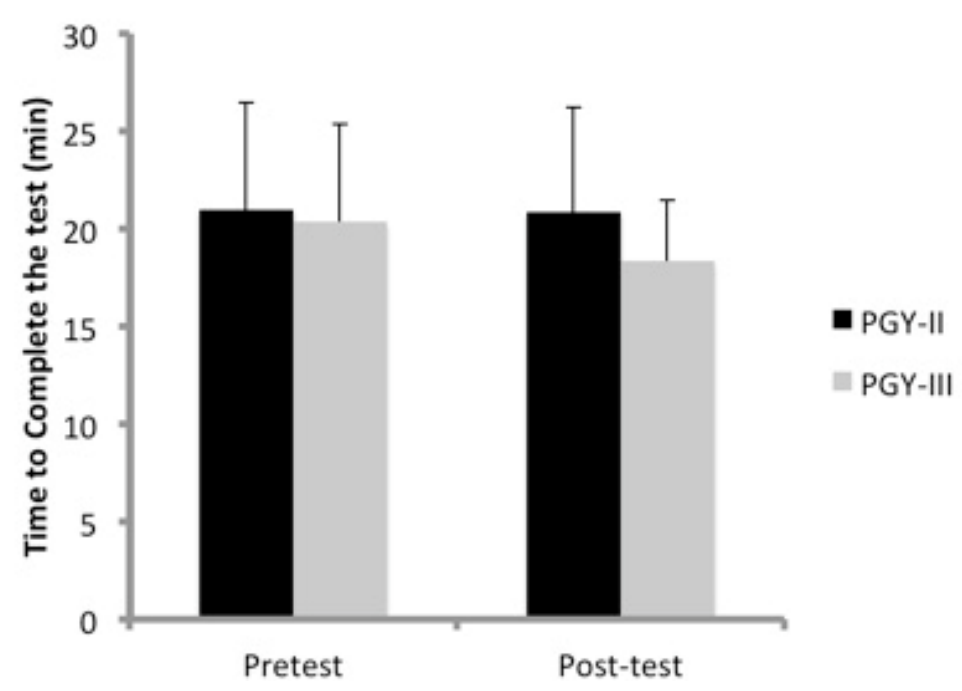

Figure 1. Time to complete the test was not different among the residents with different level of training.

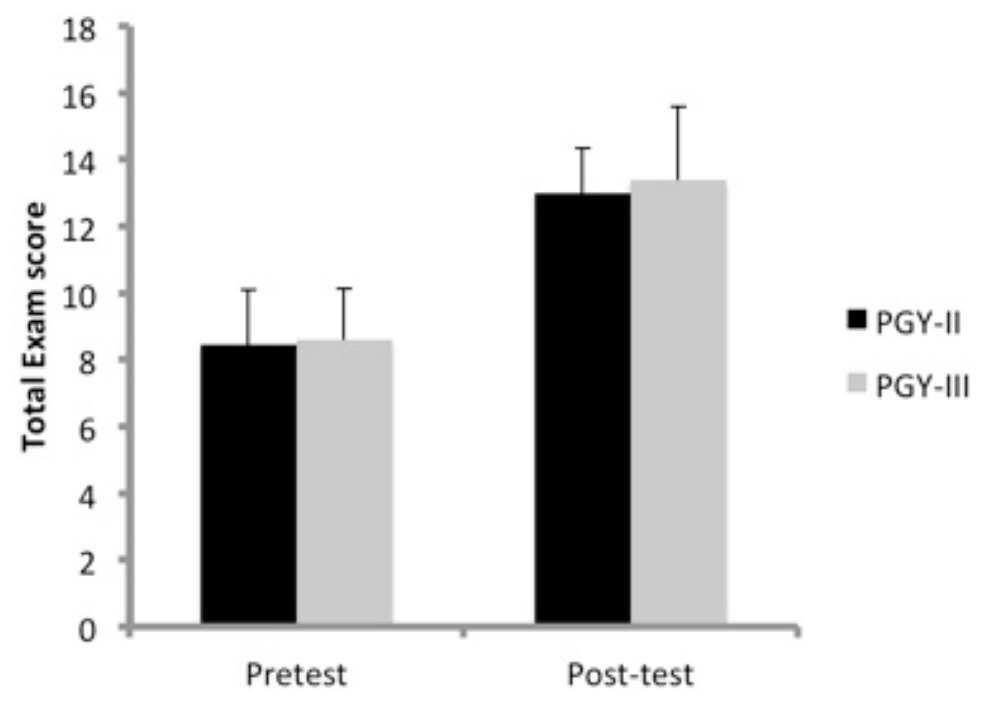

Figure 2. While there is a significant improvement in the test score after completion of the rotation, there was no difference based on the level of training.

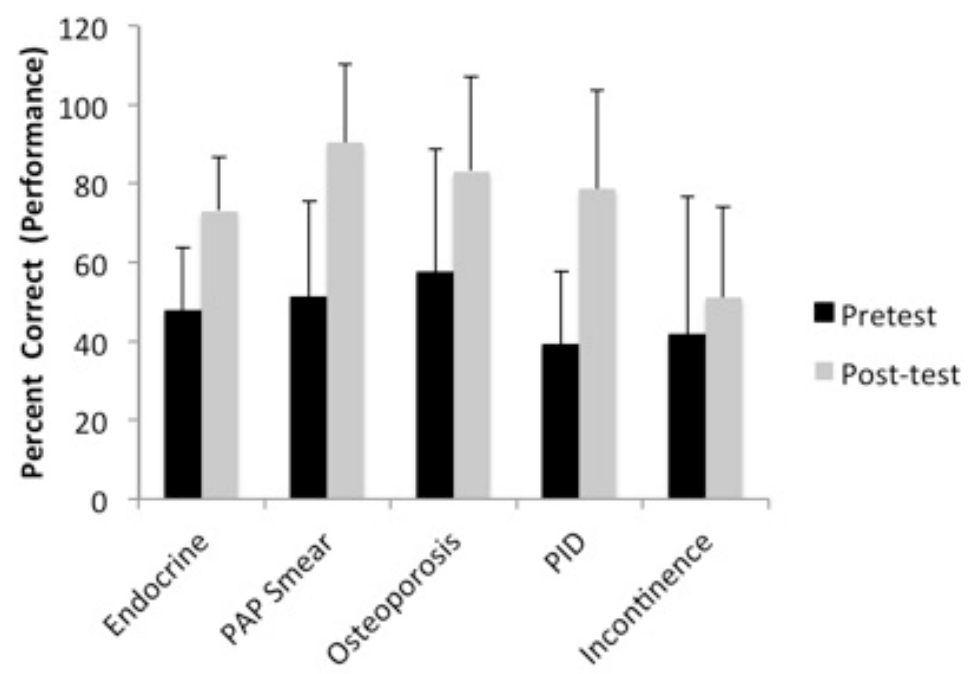

Figure 3. Improvement of test scores in various topics. 
TScPost vs TScPre

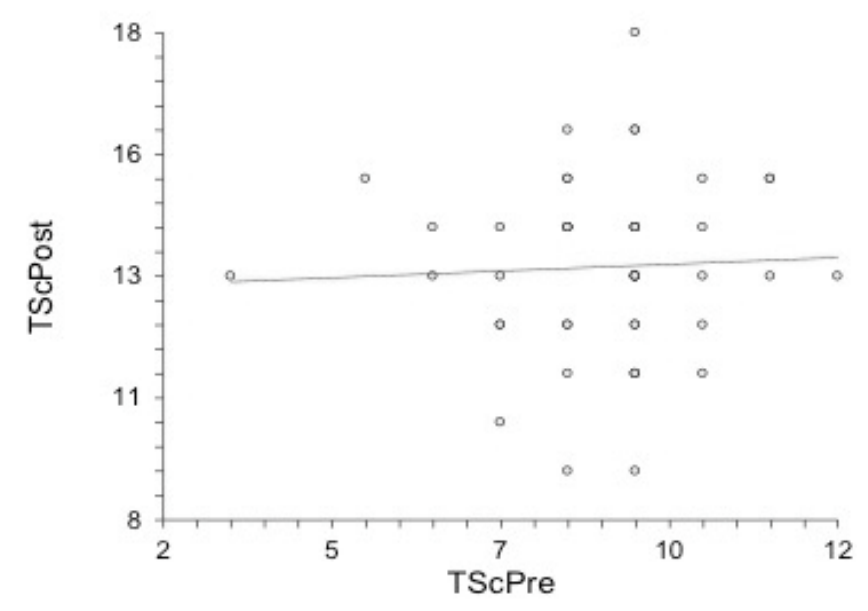

Figure 4. Correlation between the pretest scores and post-test scores.

\section{DISCUSSION}

Woman's health is increasingly being recognized as a need to be addressed. With this understanding comes the knowledge that our physicians may not have received this training and the new generation of trainees in Internal medicine who are soon going to be part of work force may still be ill equipped with this knowledge.

These objectives are to be specific, measurable, achievable, reproducible and time limited (S.M.A.R.T) [13]. Therefore, we tested the baseline medical knowledge of the medical residents by pre-test exams. The effectiveness of the teaching and the level of understanding of the residents were tested by post-test. These tests were based on clinical scenarios [14]. We have noticed that every single resident improved their understanding of women's health issues by at least $50 \%$ toward the end of their rotation. This improvement was independent of their baseline medical knowledge and their postgraduate level of training.

This gap in training has been recognized and medical schools are making a movement towards setting up curricula in women's health and have plans to teach this but there is lack of fully trained faculty in this field. Some centers have started providing fellowship programs that need 2-year time commitment and are geared towards physicians planning to spend working totally as women's health specialists. Physicians planning to be generalists and who would be managing the bulk of women patients are still not adequately trained. VA has already recognized this problem and is partnering with academic institutions to set up postgraduate fellowships and is educating its existing work force of generalists slowly by mini-residencies $[15,16]$.
This program has a practical curriculum that includes teachings on gender-specific examination and performing basic procedures [17]. Additional teachings include assessment for common vaginal discharges, skin changes and prolapse. The curriculum was set up in the form of case based problem solving to give the resident a hands-on experience [18]. This was meant to bridge the gap between theory and practice [19]. Assessment was made of patient centered care skills when residents examined the patients and came up with a plan of care [20]. There was noticeable increase in confidence of residents in handling of these issues in their primary care clinics and they reported patient satisfaction and their own pleasure in providing this care. They felt this curriculum met their needs for conceptual and practical management. Virtually all residents reported increased skill, knowledge and confidence and this could also be observed towards the end of the rotation.

This curriculum has a potential of being adopted by different training programs and that would provide a work force skilled and comfortable to address their female patient's needs. This should add up to substantial cost savings for the patients, as this will avoid the need to pay two co-pays and get timely care. It should also mean a huge cost saving for health care and the VA. As increasing numbers of female patients are enrolling for VA services this would provide trained physicians ready and skilled to provide this gender specific care and obviate ongoing cost of training.

\section{LIMITATIONS}

This is a single center study and is limited by its sample size. Additionally, the study only provides 
a cross-sectional assessment of skills and knowledge base and does not extend to their ability in applying this acquired knowledge in to their practice.

\section{CONCLUSION}

This study shows how to equip physicians in training with information on women's health that enables them to provide safe and gender appropriate care in primary care settings. This practice will reduce the need for frequent referrals for specialized care and thus provide cost saving for patient and health care on the whole.

\section{Acknowledgement. None.}

Conflict of interests. The authors declare that there are no conflicts of interest.

Introducere. Rezidenții de medicină internă trebuie să dezvolte competențe pentru îngrijirea primară dar există o lipsă în curricula lor privind patologiile sistemului reproducător feminin. Datorită creşterii numărului de paciente în vârstă se pune problema recrutării medicilor competenți pe această specializare.

Materiale şi metode. A fost realizat un curs intensiv interactiv de o lună bazat pe patologiile sistemului reproducător feminin la care au participat rezidenți de Medicină Internă. Au fost administrate examinari înaintea şi după cursul de o lună. Îmbunătăţirea cunoştiințelor privind evaluările specifice şi managementul unor astfel de pacienți au fost evaluate obiectiv prin modificările scorului obținut la examinarea după terminarea cursului intensiv.

Rezultate. Au fost evaluați 47 de rezidenți de medicină internă ce au fost în stagiu în spitalul nostru. Toți rezidenții au susținut atât examinarea dinainte și după curs. Timpul mediu de completare al testului a fost $20.5 \pm 5.4$ min inaintea cursului şi $19.5 \pm 4.8$ min după finalizarea cursului. Nu a fost nicio corelație între timpul de completare a testului înainte şi după curs. În schimb scorurile finale s-au imbunătățit semnificativ statistic de la $8.5 \pm 1.6$ la $13.2 \pm 1.8(p<0.0001)$.

Concluzii. Studiul arată o modalitate prin care medicii pot fi pregătiți în domeniul patologiilor sistemului reproducător feminin, dobândind informații privind ingrijirile specifice acestui grup de pacienți. Astfel de practici vor duce la scăderea referirilor la medicii specialişti şi astfel vor duce la scăderea costurilor atât pentru pacienți, cât şi pentru intregul sistem de sănătate.

Correspondence to: NADER D. NADER, MD, PhD, Professor of Anesthesiology and Surgery,

FACC, FCCP VA Western NY Healthcare System, Rm 204C, 3495 Bailey Ave, Buffalo, NY 14215

Tel: +17163457909

E-mail: nnader@buffalo.edu

\section{REFERENCES}

1. SIMKIN RJ. Women's health: time for a redefinition. CMAJ 1995; 152 (4):477-479.

2. CURLIN P, TINKER A. Women's health. Infect Dis Clin North Am 1995; 9 (2):335-351.

3. DOYAL L. Women, health and the sexual division of labor: a case study of the women's health movement in Britain. Int $\mathrm{J}$ Health Serv 1983; 13 (3):373-387.

4. WAYNE DB, DAROSA DA. Evaluating and enhancing a women's health curriculum in an internal medicine residency program. J Gen Intern Med 2004; 19 (7):754-759.

5. GONZALEZ DE LEON D, LEWIS J. Experiences of the network: towards unity for health women and health taskforce. Educ Health (Abingdon) 2009; 22 (2):274.

6. WASHINGTON DL, CAFFREY C, GOLDZWEIG C, SIMON B, YANO EM. Availability of comprehensive women's health care through Department of Veterans Affairs Medical Center. Womens Health Issues 2003; 13 (2):50-54.

7. FROMME HB, KARANI R, DOWNING SM. Direct observation in medical education: a review of the literature and evidence for validity. Mt Sinai J Med 2009; 76 (4):365-371. 
8. DUNSTONE DC. A neurosciences-in-psychiatry curriculum project for residents in psychiatry. Acad Psychiatry $2010 ; 34$ (1):31-38.

9. ALLERY L. Teach practical skills. Educ Prim Care 2009; 20 (1):58-60.

10. MCKIMM J. Giving effective feedback. Br J Hosp Med (Lond) 2009; 70 (3):158-161.

11. LIPNEVICH AA, SMITH JK. Effects of differential feedback on students' examination performance. J Exp Psychol Appl 2009; 15 (4):319-333.

12. YARRIS LM, LINDEN JA, GENE HERN H, LEFEBVRE C, NESTLER DM, FU R. et al. Attending and resident satisfaction with feedback in the emergency department. Acad Emerg Med 2009; 16 Suppl 2:S76-81.

13. MCKIMM J, BARROW M. Curriculum and course design. Br J Hosp Med (Lond) 2009; 70 (12):714-717.

14. DURAK HI, CALISKAN SA, BOR S, VAN DER VLEUTEN C. Use of case-based exams as an instructional teaching tool to teach clinical reasoning. Med Teach 2007; 29 (6):e170-174.

15. GREYSEN SR, WASSERMANN T, PAYNE P, MULLAN F. Teaching health policy to residents--three-year experience with a multi-specialty curriculum. J Gen Intern Med 2009; 24 (12):1322-1326.

16. TEJWANI S, MURTHY SI, GADUDADRI CS, THOMAS R, NIRMALAN P. Impact of a month-long training program on the clinical skills of ophthalmology residents and practitioners. Indian J Ophthalmol 2010; 58 (4):340-343.

17. RAMANI S. Twelve tips for excellent physical examination teaching. Med Teach 2008; 30 (9-10):851-856.

18. POLYZOIS I, CLAFFEY N, MATTHEOS N. Problem-based learning in academic health education. A systematic literature review. Eur J Dent Educ 2010; 14 (1):55-64.

19. WONG BM, ETCHELLS EE, KUPER A, LEVINSON W, SHOJANIA KG. Teaching quality improvement and patient safety to trainees: a systematic review. Acad Med 2010; 85 (9):1425-1439.

20. KASSIRER JP. Teaching clinical reasoning: case-based and coached. Acad Med 2010; 85 (7):1118-1124.

Received February 27, 2017 